\title{
Mullah Abdullah Gas turbine Performance Improvement Using Steam Injection Technique
}

\author{
Dr. A. R. Habbo Mohammed \\ Mechanical Engineering Department \\ College of Engineering, Mosul university
}

\begin{abstract}
In this study a thermal analysis and performance evaluation was carried out to investigate the benefit of using steam injection technique to Mullah Abdullah simple gas turbine generators (North of Iraq). Mullah Abdullah simple gas turbine generators was modeled and simulated to observe its performance including power output, thermal efficiency and specific fuel consumption. Thereafter, the simulation was carried out to investigate the performance of the suggested unit when a steam injection technique is used. The suggested method has been investigated and its results compared with a simple cycle results. The results indicates that the power out of the present Mullah Abdullah simple gas turbine can be held constant (37.5 MW) even the ambient temperature increase from $15{ }^{\circ} \mathrm{C}$ to $45{ }^{\circ} \mathrm{C}$ for the whole year by injecting a suitable quantity of steam, depending on ambient temperature, in its combustion chamber. The injected steam is generated by the heat recovery steam generator which extracts the thermal energy available in the exhaust gases.

Keywords:- Gas turbine, steam injection, heat recovery steam generator
\end{abstract}

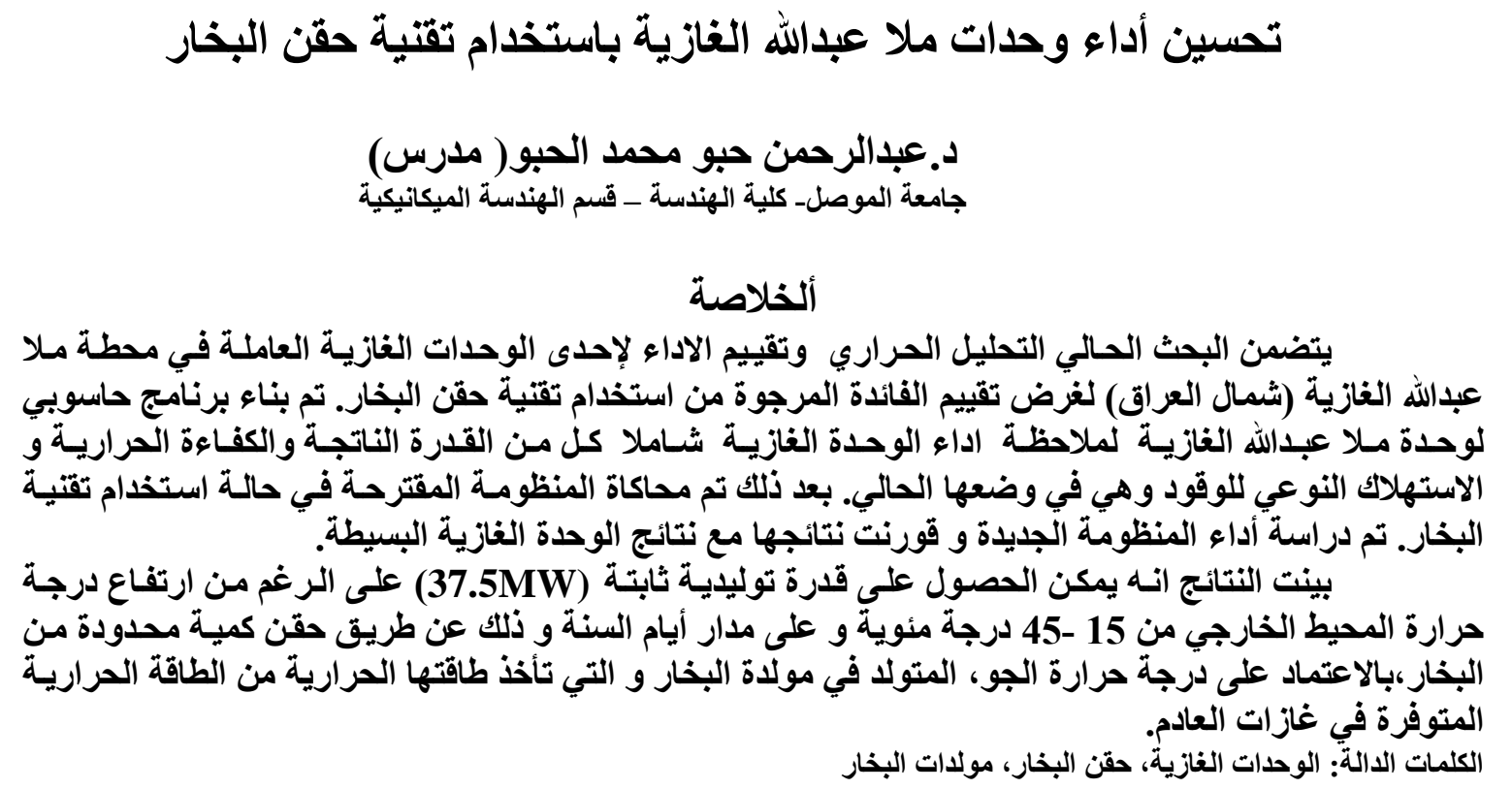

Received: 8 - 12 - 2011

Accepted: 21 - 10 - 2012 


\section{Nomenclature}

B

$\mathrm{Cp}$

FA

$\mathrm{H}$

LCV

$\mathrm{M}$

$\mathrm{P}$

$\mathrm{R}$

$\begin{array}{ll}\mathrm{r}_{\mathrm{p}} & \text { Pressure ratio } \\ \mathrm{S} & \text { Steam } \\ \mathrm{T} & \text { Temperature }(\mathrm{K}) \\ \mathrm{TIT} & \text { Turbine inlet temperature }(\mathrm{K}) \\ \mathrm{W} & \text { Work }(\mathrm{kJ}) \\ \mathrm{E} & \text { Effectiveness } \\ \mathrm{H} & \text { Efficiency } \\ \Gamma & \text { Specific heat ratio }\end{array}$

$\Delta$

Steam injection ratio

Specific heat (kJ/kg.K)

Fuel-air ratio

Specific enthalpy $(\mathrm{kJ} / \mathrm{kg})$

Lower calorific value $(\mathrm{kJ} / \mathrm{kg})$

Mass (kg)

Pressure (bar)

Specific gas constant (kJ/kg.K)

Pressure ratio

Turbine inlet temperature $(\mathrm{K})$

Work (kJ)

Efficiency

Difference
Subscripts

a Air

apr Approach point

c compressor

exh Exhaust gases

f Fuel

GT Gas turbine

HRSG Heat recovery steam generator

Los Losses

NS No steam injection

pin Pinch point

s Steam

STI Steam injection

$\mathrm{t} \quad$ turbine

tt total

1,2,3.. Thermodynamic states

\section{Introduction}

The use of gas turbine generators for producing electricity has been increased in the last three decades and likely to continue to do so in the near future. This is due to low capital cost to power ratio, efficient fuel conversion, reduced cost of electricity, low installation and maintenance cost, the high flexibility and reliability achievable with simple cycle configuration as well as the high efficiency of integrated solutions of waste heat recovery [1-6]. The performance of gas turbine generators is highly dependent on ambient temperature which varies considerably throughout the year between the summer and the winter and even throughout the day and night, and this is the real case of Mullah Abdullah gas turbine generators. Therefore, it is so important to look for ways to improve gas turbine performance based cycles with no modification to existing gas turbine generators is made. The exhaust gases of gas turbine generators leaving the turbine carrying a significant amount of thermal energy, is usually expelled to atmosphere without taking any further role in the power generation process, as the current case of Mullah Abdullah gas turbine generators. Therefore, this thermal energy can be used as an energy source in a heat recovery steam generator where energy is transferred from the exhaust gases to the boiler feed water for producing high pressure superheated steam. This high pressure steam, is then can be injected into the combustor chamber of gas turbine generator [7-12]. The air from the compressor and the steam from the heat recovery steam generator (HRSG), both receive fuel energy in the combustion chamber and both expand inside the same turbine to boost the power output of turbine since the specific heat of superheated steam is almost double the value of air and the enthalpy of steam is higher than that of air at a certain temperature. 
Therefore, the steam injection method"STIG" seems a very effective way to boost the net power output and increase the overall efficiency of gas turbines. The amount of steam generated in the heat recovery steam generator from the gas turbine depends upon the pinch point and the approach point of the boiler [[10-12]. Heat recovery steam generator performance is usually based on the concept of pinch point and approach point that govern the gas and steam temperature profile. The pinch point represent the difference between the gas temperature leaving the evaporator and saturation temperature, while the approach point temperature is the difference between the water temperature leaving the economizer and saturation temperature as shown in figure(1).

Mullah Abdullah gas turbine power station comprises of several gas turbine generators, each of them of $37.5 \mathrm{MW}$ power output at ISO conditions ( 1 bar and $15^{\circ} \mathrm{C}$ ) operating on simple cycle mode with compressor pressure ratio of 8 and turbine inlet temperature of $950{ }^{\circ} \mathrm{C}$. Therefore, in the current study an investigation will be carried out to assess the benefit of having heat recovery steam generator for producing superheated steam. The extracting thermal energy from gas turbine exhaust gases, to be injected in the gas turbine combustion chamber to keep the performance of existing gas turbine units when operate on hot weather conditions as the same as that of ISO conditions including the power output, thermal efficiency and specific fuel consumption.

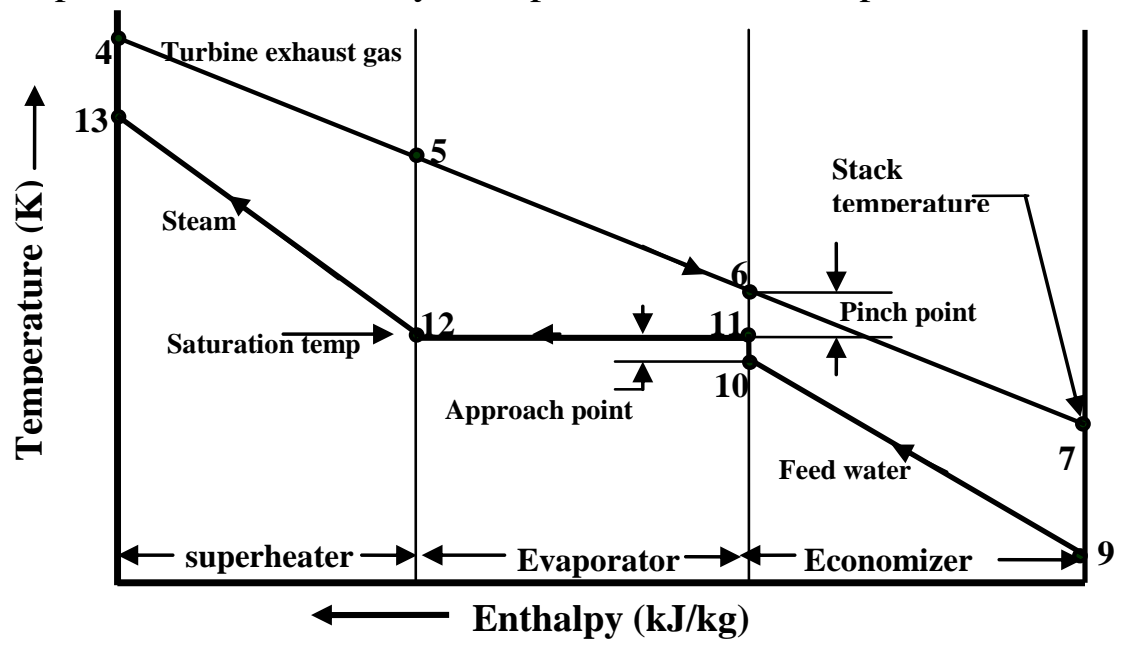

Figure (1): Temperature profile in a single pressure HRSG

\section{Gas Turbine Unit}

Gas turbines are steady flow heat engines consisting of three main components, an axial flow compressor, a combustion chamber and an axial flow turbine. A schematic diagram for a simple single shaft gas turbine like those is used in Mullah Abdullah power station is shown in figure (2). Air is drawn into the gas turbine by the compressor, which compresses and delivers it to the combustion chamber. Within the combustion chamber the air is mixed with fuel and

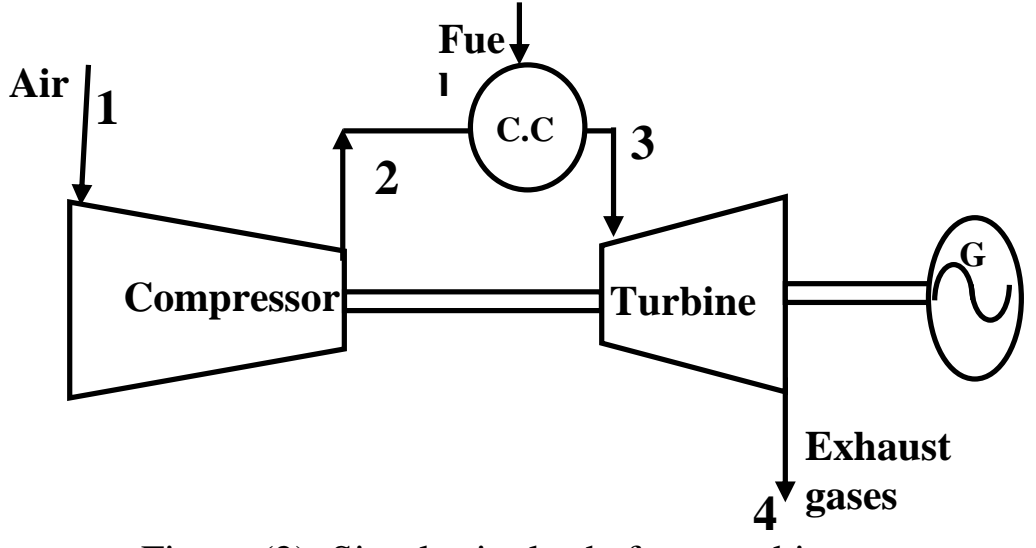

Figure (2): Simple single shaft gas turbine 
the mixture is ignited, producing a rise in temperature of exhaust gases. These exhaust gases enter the turbine, expand which produce work and finally discharge to atmosphere $[1,2]$.

\section{Proposed Gas Turbine Cycle with Steam Injection}

The proposed cycle comprises of the single shaft gas turbine, heat recovery steam generator and steam pipeline to carry the high pressure steam from the heat recovery steam generator and deliver it to the combustion chamber. However, the pressure required to inject the steam into the combustion chamber is relatively low compared to that usually employed in steam turbine. So the required heat recovery steam generator can be a very simple in design, with a single pressure level and low pinch and approach point, thus reducing the stack temperature and increasing heat recovery. The schematic diagram of the proposed cycle is shown in figure (3).

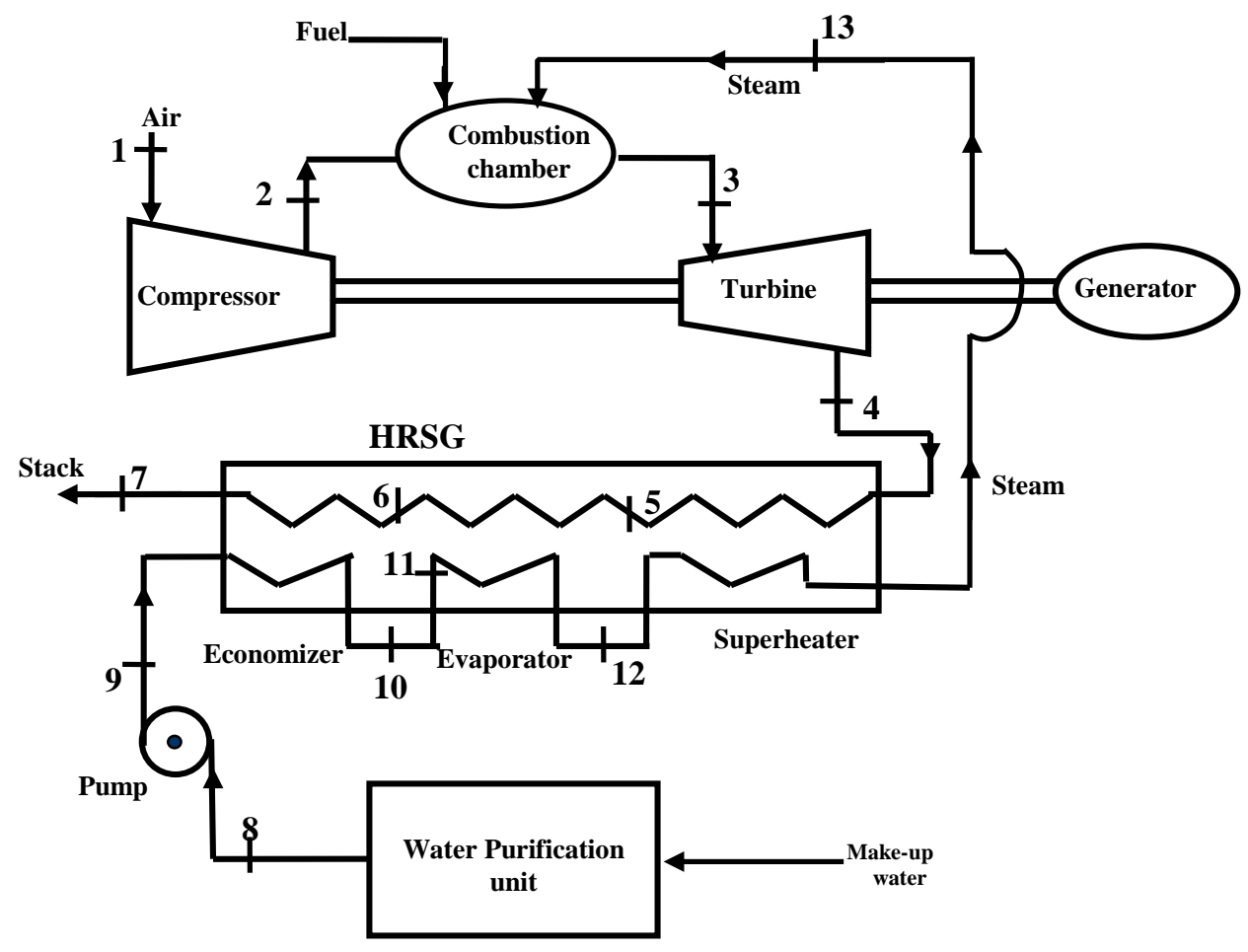

Figure (3): Schematic diagram of the proposed steam injection gas turbine

\section{Thermal Cycles Analysis}

The following assumptions are considered in thermal analysis of the simple Mullah Abdullah gas turbine generators and the proposed gas-steam injection cycle for the present study:

1. Air and exhaust gases are treated as ideal gases whose thermodynamic properties are temperature dependent

2. The fuel is methane $\mathrm{CH}_{4}$ and combustion is complete and adiabatic

3. There is no pressure loss in the inlet and exhaust ducting

4. The effectiveness of heat recovery steam generator is constant

5. Compressor and turbine are characterized with polytrophic efficiency 


\section{Compressor Section}

Figure (4) show the T-

$S$ diagram for the single gas turbine cycle, the ideal and actual processes are represented in dashed and full line respectively. In the axial compressor, air is drawn from atmosphere and compressed from point 1 to point 2 . The mass flow rate of air inducted by the compressor is calculated as follows

$$
\mathrm{m}=\rho \mathrm{C}_{\mathrm{a}} \mathrm{A}
$$

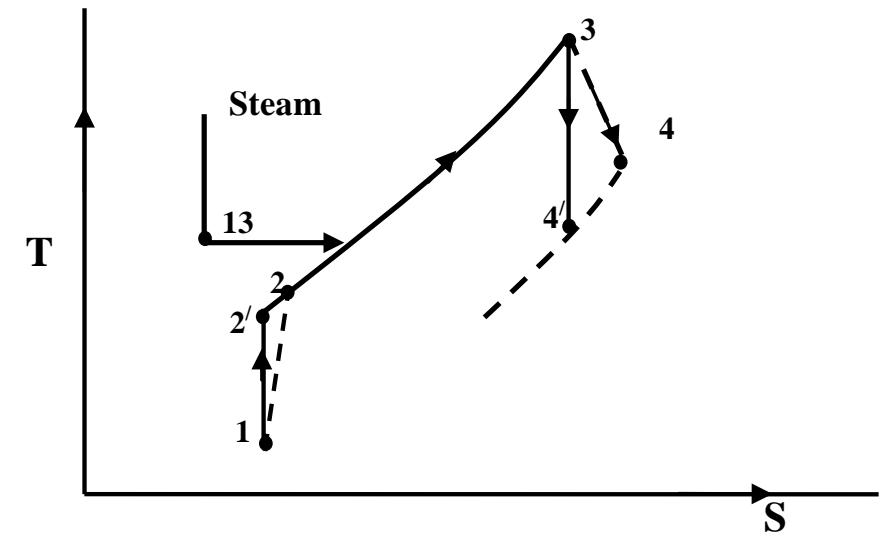

Figure (4): T-S diagram for simple gas turbine with steam injection

where

$\rho$ : density of air at inlet of compressor $\left(\mathrm{kg} / \mathrm{m}^{3}\right)$

$\mathrm{C}_{\mathrm{a}}$ : axial velocity $(\mathrm{m} / \mathrm{s})$

A: the annulus area $\left(\mathrm{m}^{2}\right)$

The density of air is calculated as follows

$\rho_{\mathrm{a}}=\frac{\mathrm{P}_{1}}{\mathrm{R} \mathrm{T}_{1}}$

The ideal compressor exit temperature may be obtained using the following formula

$\mathrm{T}_{2^{\prime}}=\mathrm{T}_{1}\left(\mathrm{r}_{\mathrm{p}}\right)^{\frac{\gamma_{\mathrm{a}}-1}{\gamma_{\mathrm{a}}}}$

And by introducing the compressor isentropic efficiency, the actual compressor exit temperature can be obtained as

$$
\mathrm{T}_{\mathrm{a}, 2}=\left[\frac{\left(\mathrm{T}_{\mathrm{a}, 2^{\prime}}-\mathrm{T}_{\mathrm{a}, 1}\right)}{\eta_{\mathrm{c}}}+\mathrm{T}_{\mathrm{a}, 1}\right]
$$

Hence the compressor work can be determined as follows

$$
\mathrm{W}_{\mathrm{c}}=\mathrm{mc}_{\mathrm{P}_{\mathrm{a}}}\left(\mathrm{T}_{\mathrm{a}, 2}-\mathrm{T}_{\mathrm{a}, 1}\right)
$$

Where $c_{\mathrm{P}_{2}}$ is the specific heat of air at constant pressure, and calculated as follows [8]

$$
\mathrm{c}_{\mathrm{P}_{\mathrm{a}}}=\left[28.11+0.1967 * 10^{-2} * \mathrm{~T}+0.4802 * 10^{-5} * \mathrm{~T}^{2}-1.966 * 10^{-9} * \mathrm{~T}^{3}\right] / 29
$$

\section{Combustion Section}

In the combustion chamber, the heat supplied is due to combustion of hydrocarbon fuel, which is considered as $\mathrm{CH}_{4}$ of lower calorific value of $50000 \mathrm{~kJ} / \mathrm{kg}$ and steam from heat recovery steam generator is injected. Therefore, the thermal processes occur in the combustion chamber may be expressed as follows: 


$$
\begin{aligned}
\mathrm{C}_{\mathrm{x}} \mathrm{H}_{\mathrm{y}}+\mathrm{z}\left(\frac{\mathrm{x}+\mathrm{y}}{4}\right)\left[\mathrm{O}_{2}+3.76 \mathrm{~N}_{2}\right]+\mathrm{aH}_{2} \mathrm{O} \rightarrow \mathrm{xCO}_{2}+ \\
\quad\left[(\mathrm{z}-1)\left(\mathrm{x}+\frac{\mathrm{y}}{4}\right)\right] \mathrm{O}_{2}+\left[3.76\left(\frac{\mathrm{x}+\mathrm{y}}{4}\right)\right] \mathrm{N}_{2}+\left(\frac{\mathrm{y}}{2}+\mathrm{a}\right) \mathrm{H}_{2} \mathrm{O}
\end{aligned}
$$

The variation of parameters when steam is injected in the combustion chamber can be assessed by applying the steady flow energy equation to the combustion chamber which has been considered as a control volume as shown in figure (5). An energy balance over the combustion chamber for dry (no steam injection) and wet (with steam injection) operation can be made as follows:

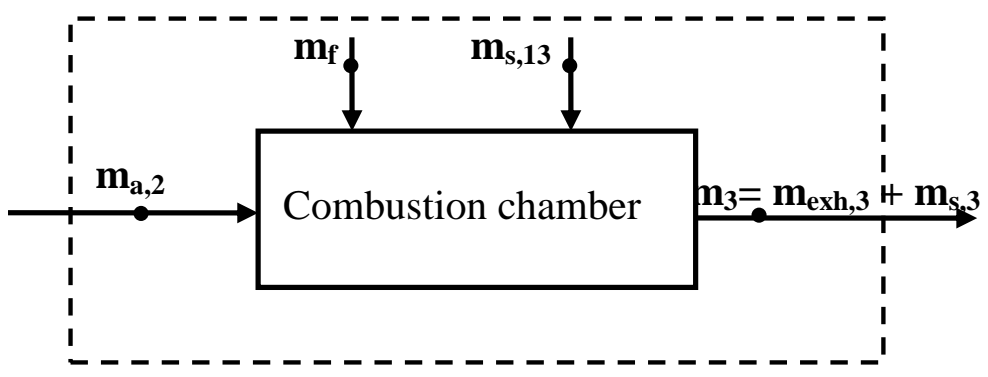

Figure (5): Control volume for application of the SFEE for the combustion chamber

\section{- Dry operation ( no steam injection)}

The energy balance can be written as

$$
\begin{aligned}
& \mathrm{m}_{\mathrm{a}} * \mathrm{~h}_{\mathrm{a}, 2}+\mathrm{m}_{\mathrm{f}} * \mathrm{LCV}=\left(\mathrm{m}_{\mathrm{a}}+\mathrm{m}_{\mathrm{f}}\right) * \mathrm{~h}_{\mathrm{exh}, 3} \\
& \mathrm{~m}_{\mathrm{a}} *\left(\mathrm{~h}_{\mathrm{a}, 2}-\mathrm{h}_{\mathrm{exh}, 3}\right)=\mathrm{m}_{\mathrm{f}} *\left(\mathrm{~h}_{\mathrm{exh}, 3}-\mathrm{LCV}\right)
\end{aligned}
$$

Where $h_{a, 2}$ is the specific enthalpy of air leaving the compressor and calculated as

$$
\mathrm{h}_{\mathrm{a}, 2}=\mathrm{c}_{\mathrm{P}_{\mathrm{a}}} \mathrm{T}_{\mathrm{a}, 2}
$$

and $h_{\text {exh,3}}$ is the specific enthalpy of combustion product leaving the combustion chamber and calculated as follows

$\mathrm{h}_{\mathrm{exh}, 3}=\mathrm{c}_{\mathrm{P}_{\mathrm{g}}} \mathrm{T}_{\mathrm{exh}, 3}$

Specific enthalpy of combustion product is calculated as follows[8]

$\mathrm{c}_{\mathrm{P}_{\mathrm{exh}}}=\left[1.083-2.3127 * 10^{-3} * \mathrm{~T}+4.0405 * 10^{-6} * \mathrm{~T}^{2}-1.7363 * 10^{-9} * \mathrm{~T}^{3}\right]$

Hence the fuel - air ratio without steam injection can be expressed as

$$
\mathrm{FA}_{\mathrm{NS}}=\frac{\mathrm{m}_{\mathrm{f}}}{\mathrm{m}_{\mathrm{a}}}=\frac{\mathrm{h}_{\mathrm{a}, 2}-\mathrm{h}_{\mathrm{exh}, 3}}{\mathrm{~h}_{\mathrm{exh}, 3}-\mathrm{LCV}}
$$

\section{- Wet operation (with steam injection)}

In the case of wet operation the energy equation is given as

$$
\mathrm{m}_{\mathrm{a}} * \mathrm{~h}_{\mathrm{a}, 2}+\mathrm{m}_{\mathrm{f}} * \mathrm{LCV}+\mathrm{m}_{\mathrm{s}, 13} * \mathrm{~h}_{\mathrm{s}, 13}=\left(\mathrm{m}_{\mathrm{a}}+\mathrm{m}_{\mathrm{f}}\right) * \mathrm{~h}_{\mathrm{exh}, 3}+\mathrm{m}_{\mathrm{s}, 3} * \mathrm{~h}_{\mathrm{s}, 3}
$$

And since $\mathrm{m}_{\mathrm{s}, 13}=\mathrm{m}_{\mathrm{s}, 3}=\mathrm{m}_{\mathrm{s}}$, therefore, equation (10) can be written as follows $\mathrm{m}_{\mathrm{a}} *\left(\mathrm{~h}_{\mathrm{a}, 2}-\mathrm{h}_{\mathrm{exh}, 3}\right)+\mathrm{m}_{\mathrm{s}}\left(\mathrm{h}_{\mathrm{s}, 13}-\mathrm{h}_{\mathrm{s}, 3}\right)=\mathrm{m}_{\mathrm{f}} *\left(\mathrm{~h}_{\mathrm{exh}, 3}-\mathrm{LCV}\right)$ 
Therefore, the fuel-air with steam injection technique can be written as follows

$$
\mathrm{FA}_{\mathrm{STI}}=\frac{\mathrm{m}_{\mathrm{f}}}{\mathrm{m}_{\mathrm{a}}}=\frac{\left(\mathrm{h}_{\mathrm{exh}, 3}-\mathrm{h}_{\mathrm{a}, 2}\right)+\mathrm{B}\left(\mathrm{h}_{\mathrm{s}, 3}-\mathrm{h}_{\mathrm{s}, 13}\right)}{\left(\mathrm{LCV}-\mathrm{h}_{\mathrm{exh}, 3}\right)}
$$

Where $\quad B=\frac{m_{s}}{m_{f}}$ : steam injection ratio

\section{Turbine Section}

The turbine of an axial flow type consists of five rows of blades. The hot gases leaving the combustion chamber expand in the turbine and produce work. The mathematical calculation for the turbine can be presented as follows:

The isentropic turbine outlet temperature is given as

$\mathrm{T}_{\text {exh, } 4^{\prime}}=\mathrm{T}_{\mathrm{exh}, 3}\left(\frac{1}{\mathrm{r}_{\mathrm{P}}}\right)^{\frac{\gamma_{\mathrm{exh}}-1}{\gamma_{\mathrm{exh}}}}$

And the actual turbine outlet temperature can be obtained as follows:

$\mathrm{T}_{\mathrm{exh}, 4}=\mathrm{T}_{\mathrm{exh}, 3}-\eta_{\mathrm{t}}\left(\mathrm{T}_{\mathrm{exh}, 3}-\mathrm{T}_{\mathrm{exh}, 4^{\prime}}\right)$

Hence, the turbine work is

$\mathrm{W}_{\mathrm{t}}=\left(\mathrm{m}_{\mathrm{a}}+\mathrm{m}_{\mathrm{f}}\right) *\left(\mathrm{~h}_{\mathrm{exh}, 3}-\mathrm{h}_{\mathrm{exh}, 4}\right)+\mathrm{m}_{\mathrm{s}}\left(\mathrm{h}_{\mathrm{s}, 3}-\mathrm{h}_{\mathrm{s}, 4}\right)$

The power output is obtained as follows

$\mathrm{P}_{\mathrm{GT}}=\mathrm{W}_{\mathrm{t}}-\mathrm{W}_{\mathrm{c}}$

The thermal efficiency is found using the following equation

$\eta_{\mathrm{GT}}=\frac{\mathrm{P}_{\mathrm{GT}}}{\mathrm{Q}_{\mathrm{add}}}=\frac{\mathrm{P}_{\mathrm{GT}}}{\mathrm{m}_{\mathrm{f}} * \mathrm{LCV}}$

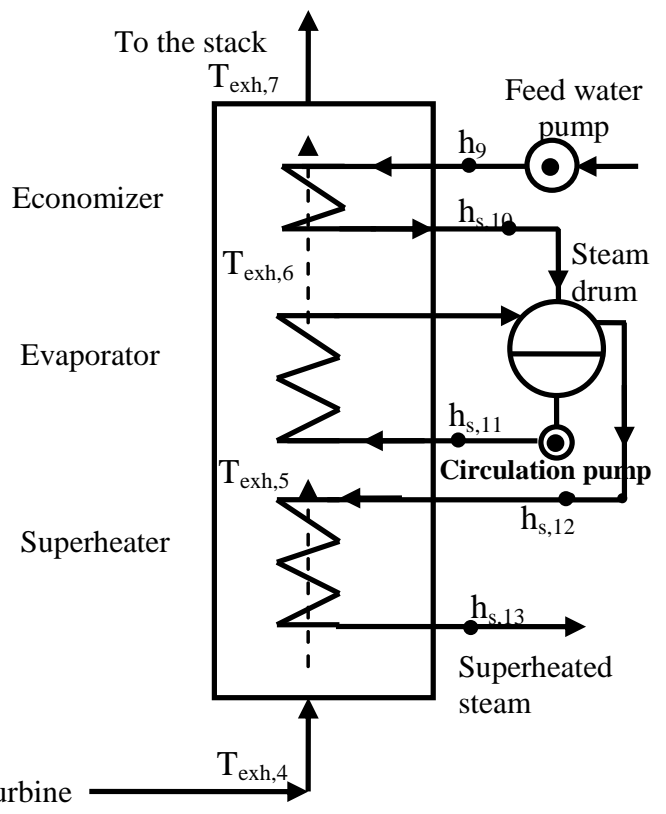

Heat recovery steam generator

The heat recovery steam generator (HRSG) mainly consists of economizer evaporator and superheater. In present study a single pressure heat

Gas turbine exhaust

Figure (6): Heat recovery steam generator component recovery steam generator is adopted to produce steam at suitable pressure and temperature to be injected in the gas turbine combustion chamber as shown in figure (6). 
The key figure in the heat recovery steam generator is the pinch point and the approach point. The pinch point temperature can be obtained as follows

$\Delta \mathrm{T}_{\mathrm{pin}}=\mathrm{T}_{\mathrm{exh}, 6}-\mathrm{T}_{\mathrm{s}, 11}$

While the approach point temperature can be assessed as follows:

$\Delta \mathrm{T}_{\mathrm{apr}}=\mathrm{T}_{\mathrm{s}, 12}-\mathrm{T}_{\mathrm{s}, 10}$

The steam generation rate in the heat recovery steam generator is determined by considering a control volume of the superheater and evaporator and performing an energy balance which yield to

$\mathrm{m}_{\mathrm{s}}=\frac{\mathrm{m}_{\mathrm{tt}} \mathrm{c}_{\mathrm{P}_{\mathrm{exh}}}\left(\mathrm{T}_{\mathrm{exh}, 4}-\mathrm{T}_{\mathrm{exh}, 6}\right)\left(1-\mathrm{h}_{\mathrm{Los}}\right)}{\left(\mathrm{h}_{\mathrm{s}, 13}-\mathrm{h}_{\mathrm{s}, 10}\right)}$

The heat recovery steam generator effectiveness is given as

$\varepsilon_{\mathrm{HRSG}}=\frac{\mathrm{m}_{\mathrm{s}}\left(\mathrm{h}_{\mathrm{s}, 13}-\mathrm{h}_{9}\right)}{\mathrm{m}_{\mathrm{tt}} \mathrm{c}_{\mathrm{P}_{\mathrm{exh}}}\left(\mathrm{T}_{\mathrm{exh}, 4}-\mathrm{T}_{\mathrm{exh}, 7}\right)}$

\section{Results and Discussions}

The performance analysis of the suggested steam injection cycle wi has been carried out for the following $\mathrm{rp}=8, \eta_{\mathrm{c}}=0.85$ and $\eta_{\mathrm{t}}=0.88$.

Figure (7) compares the gas turbine power output with and without steam injection for wide range of ambient temperatures.

It can be seen that the power output decreases nearly by $28 \%$ as the ambient temperature increases from $5{ }^{\circ} \mathrm{C}$ to $45^{\circ} \mathrm{C}$. This is because of the density of air decreases as the ambient increase which affects the mass of air admitted to the gas turbine compressor and ultimately affects the power output

The influence of steam injection ratio $(\mathrm{B})$ on the gas turbine thermal efficiency is shown in figure(8). It can be noted that the thermal increase nearly by $7 \%$ when a steam injection technique is applied to gas turbine generator. This due to the increase of gas turbine work and the slight reduction of burned fuel.
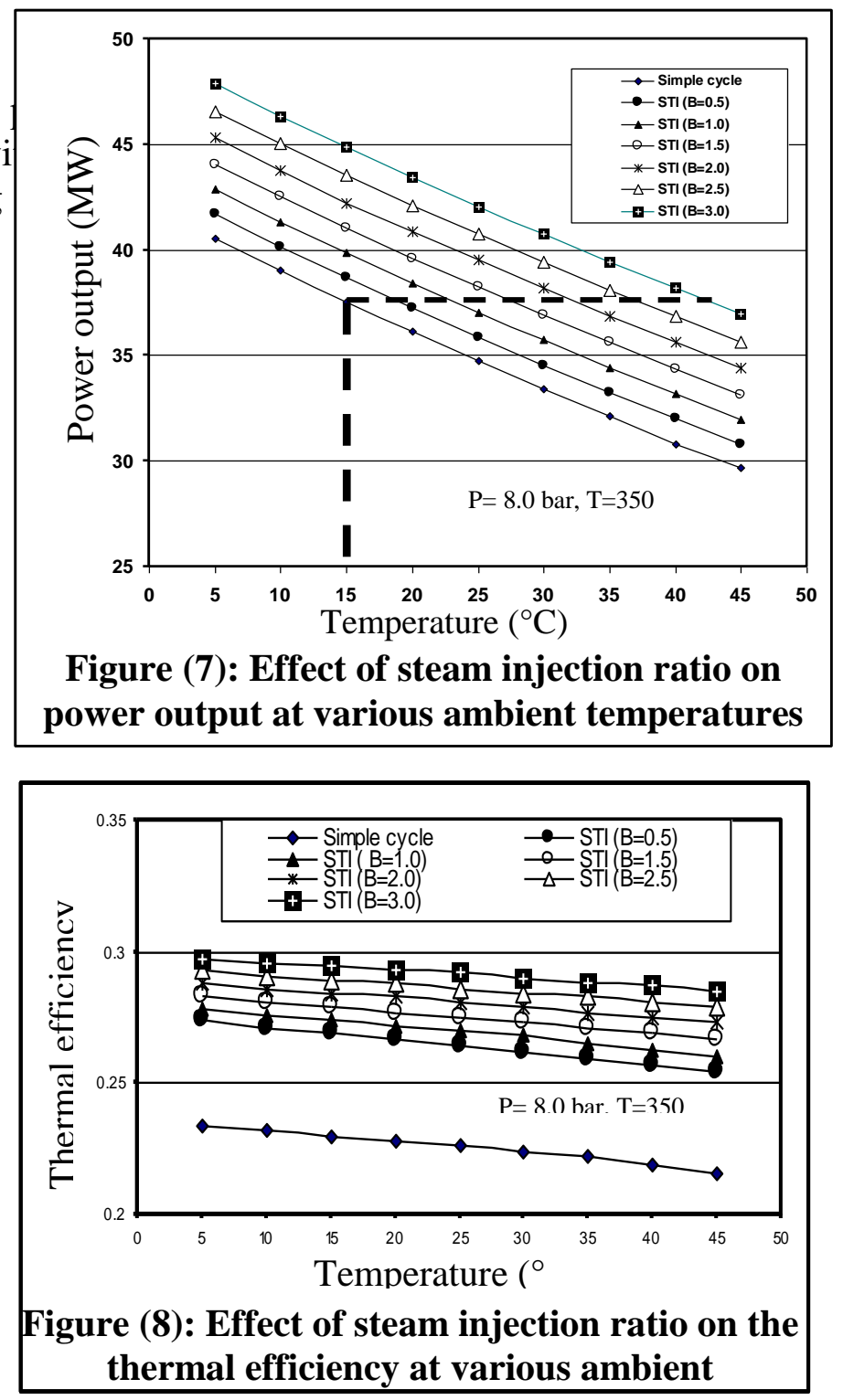
Figure (9) shows the relationship between the specific fuel consumption and ambient temperature for various values of steam injection ratio. It can be seen that the specific fuel consumption slightly increases as ambient temperature increases. This is due to the reduction in compressor mass flow rate air which eventually leads to obvious reduction in gas turbine power output. On other hand the specific fuel consumption was found to be decreased as the injection steam ratio increases from $\mathrm{B}=0.5$ to 3.0 .

This is evident because when the steam injection ratio increases, the power out put will increase and mass flow of fuel decrease since the combustion chamber temperature is kept constant. Figure(10) gives the relationship between the

quantity of steam injection ratio and ambient temperature for constant power production (ISO rate power)for different values of steam injection temperatures. It can be seen that raising the steam injection temperature for fixed steam injection pressure (8 bar) would have very little effect on the quantity of steam injection ratio. This may be explained as first to the small differences in the enthalpy content of the injected steam and second to the small amount of steam injected. According to the pictured results in figure (10), the values of steam temperature injected is chosen to be $350{ }^{\circ} \mathrm{C}$ since this temperature is achievable with aid of single heat recovery steam generator.

Moreover, different values of steam injection pressure are used in current study to investigate the effect of steam injection pressure on the required mass flow rate of

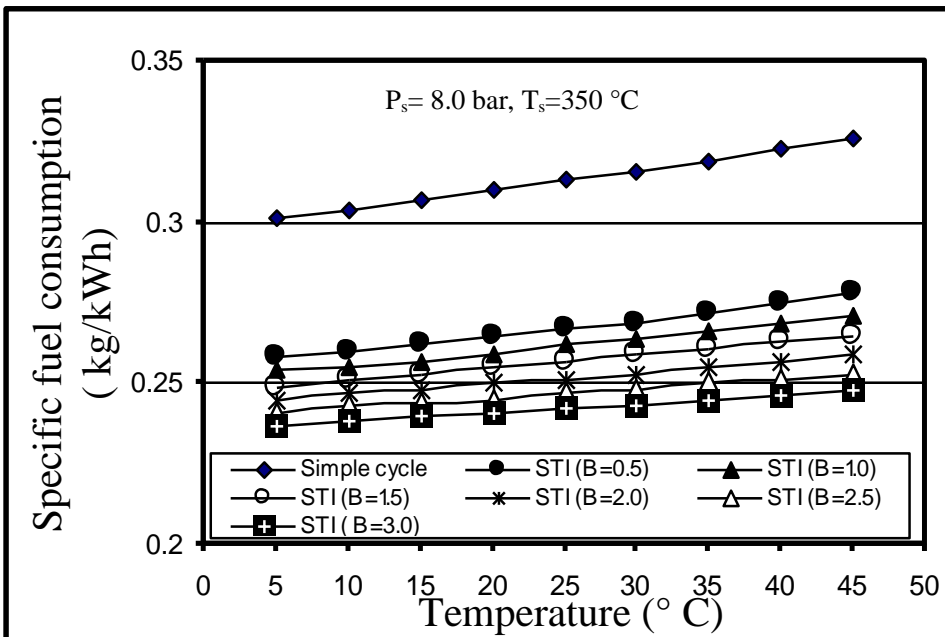

Figure (9): Effect of steam injection ratio on the SFC at various ambient temperatures

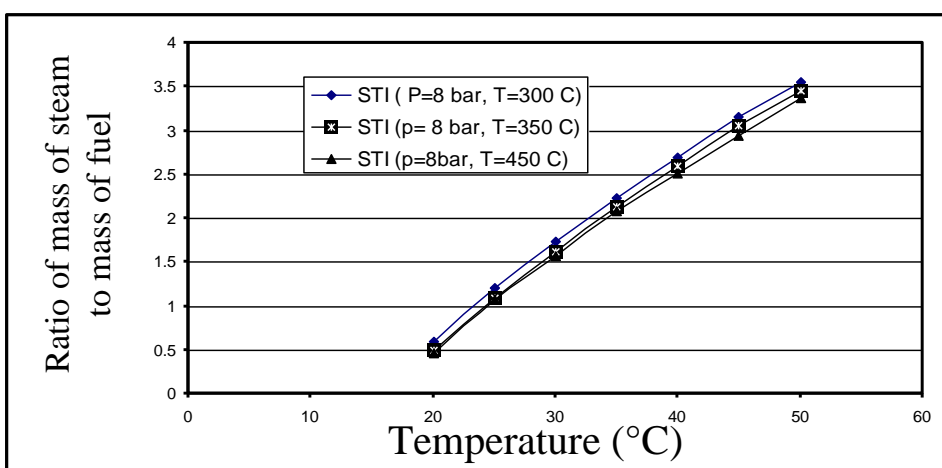

Figure (10): The relationship between the steam injection ratio and ambient temperature for constant power production for different steam

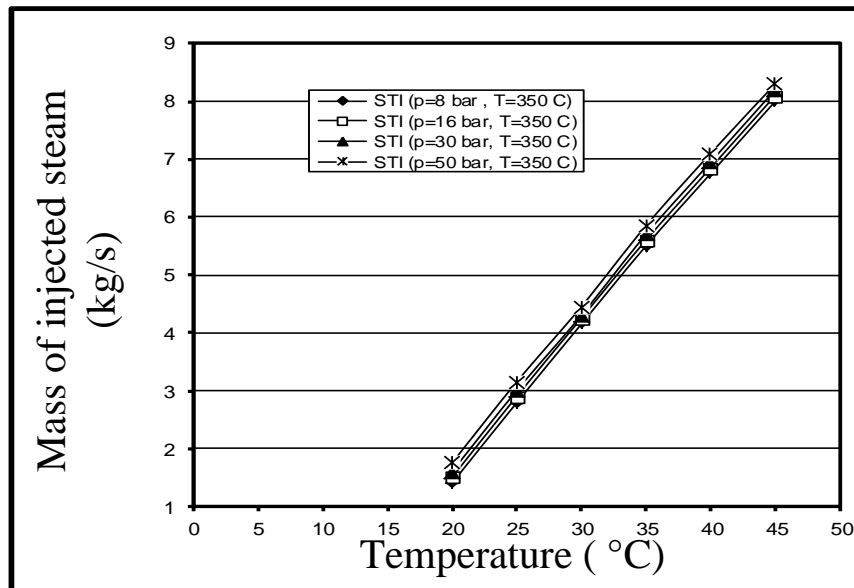

Figure (11): The relationship between the mass of injected steam and ambient temperature for values of steam pressure 
injected steam for constant power production as shown in figure (11). Again no significant effect has been observed and likely the explanations of that as the same reasons are given in figure (10). Therefore, according to figure (10) and (11), the steam injection pressure and temperature have been taken to 8 bar and $350{ }^{\circ} \mathrm{C}$ respectively.

Finally, figure (12) and (13), show the relationship between the pinch point approach point and heat recovery steam thermal efficiency. It was found the heat recovery steam thermal efficiency decreases as those points increases from $5^{\circ} \mathrm{C}$ to $40{ }^{\circ} \mathrm{C}$.

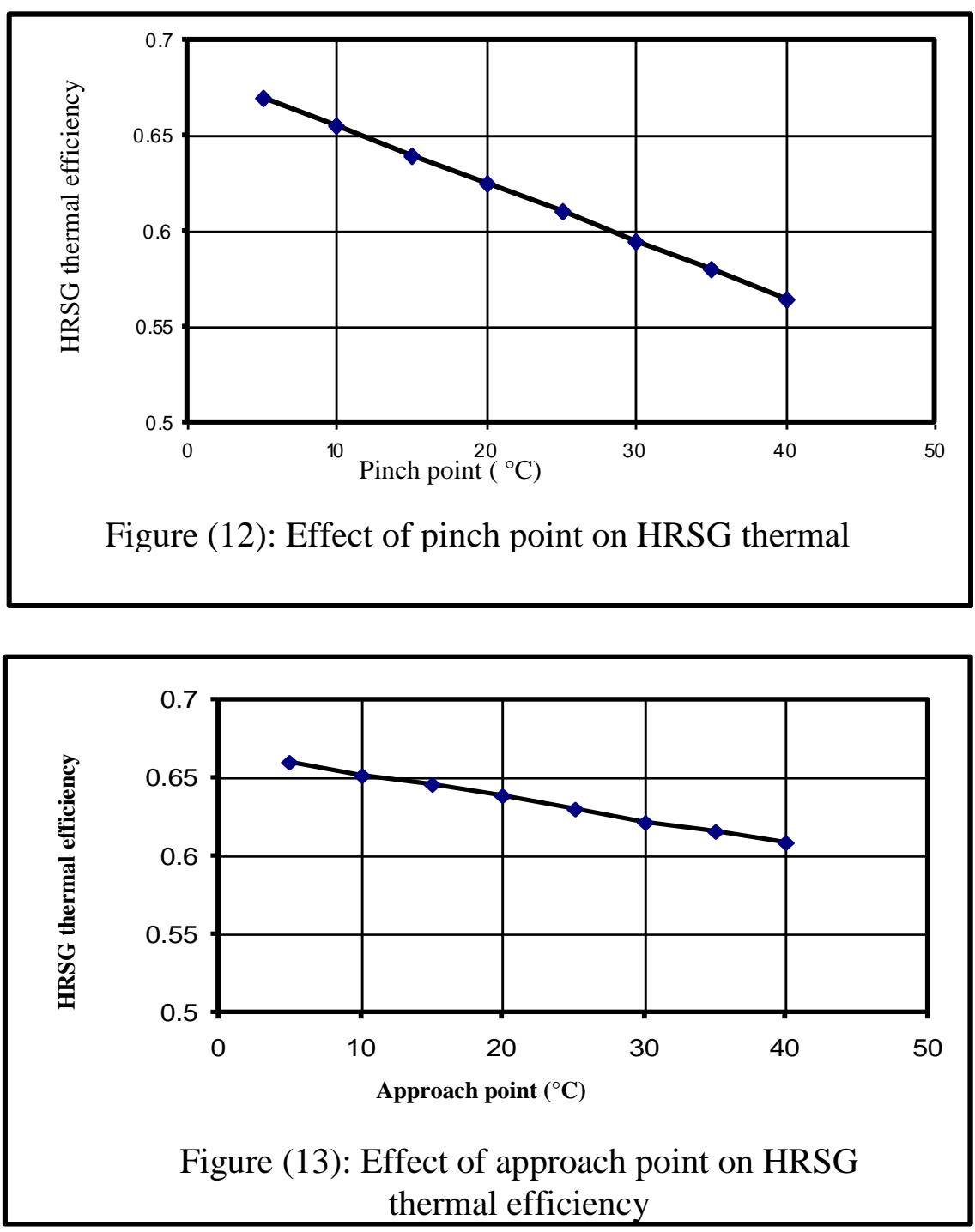

\section{References}

1- H. Cohen. G F Rogers and H. H. Saravanamuttoo., Gas Turbine Theory, Fourth edition, Longman group, Harlew, England, 1996.

2- N.V. Khartchenko, Advanced Energy Systems, Taylor and Francis, Washington DC, 1998.

3- Paepe M.D, Dick E., Cycle Improvements to Steam Gas Turbines, International Journal of of Energy Research,Vol.24, pp 1081-1107, 2000

4- Traverse A., Massardo A.F, Thermo-economic Anaylsis of Mixed Gas-Steam Cycles, Applied Thermal Engineering Journal, Vol. 22, pp1-21, 2002 
5- X. Q. Kang, R.Z . Wang, X.H.Huang, Energy Optimization Mode for A CCHP System with Available Gas Turbines, Applied Thermal Engineering,Vol.5, pp377-391, 2005

6- Roberto Carapellucci, A Unified Approach to Assess Performance of Different Techniques for Recovering Exhaust Heat From Gas Turbines, Energy Conversion and Management Journal, Vol.50, pp1218-1226, 2009

7- Ashok Kumar, S S Kahwaha and R S Mishra, Thermodynamic Analysis of a Regenrative Gas Turbine Cogeneration Plants, Journal of Scientific and Industrial Research, Vol.61, pp 225-231, March 2010

8- O Singh and R Yada, Comparative Evaluation of Combined Gas/Steam Cycle Configuration, Journal of the Institution of Engineering (India) Vol.83, No.2, pp 84-88, July 2002.

9- Franco, C. Casarosa, On Some Perspectives for Increasing the Efficiency of Combined Cycle Power Plants, Applied Thermal Engineering Journal, Vol 22 , pp1501-1518, 2002

10- A.Bouam, S.Aissani and R.Kadi, Gas Turbine Performance Improvement Using Steam Injection in the Combustion Chamber Under Sahara Conditions, Oil and Gas Science and Technology Vol.63, No.22, pp251-261 2008.

11-C. Casarosa, A. Franco, Thermodynamic Optimization of the Operative Parameters for the Heat Recovery in Combined Plants, International Journal of Applied Thermodynamics Vol.4, pp 43-52, 2001.

12- Kyoung Hoon Kim and Giman Kim, Thermodynamic Performance Assessment of Steam Injection Gas Turbine Systems, World Academy and Science ,Engineering and Technology Vol.68, pp1137-1143, 2010 